\title{
Derleme
}

Mersin Üniv Sağlık Bilim Derg 2020;13(3):444-456

doi:10.26559/mersinsbd.687364

\section{Şeker bağımlılığı: Gerçek mi hayal ürünü mü?}

\author{
(DSSabriye Arslan', (i) İdil Demet İmamoğlu², (DHilal Yıldıran ${ }^{1}$ \\ ${ }^{1}$ Gazi Üniversitesi, Sağlık Bilimleri Fakültesi, Beslenme ve Diyetetik Bölümü, Ankara \\ ${ }^{2}$ Uzman, Beslenme Danışmanlığı Merkezi, Çankaya, Ankara
}

\section{Öz}

Şeker, hem enerji içeriği hem de tadı nedeniyle beynimizdeki ödül sistemini tetikleyen lezzetli bir besindir ve yiyecek bağımlılığına neden olan işlenmiş besinlerin ana yüzünü oluşturmaktadır. Şekerin beyindeki, genel etkileri ve özellikle de beynin ödül yolaklarında etkileri yoğun bir araștırma ve tartışma alanı olmuștur. Şeker tüketimi, mezokortikolimbik sistemi madde kullanımıyla benzer șekilde aktive eder. Şeker alımına bağlı olarak beyinde dopamin D1 reseptör bağlanmasında artıș ve D2 reseptör bağlantısında azalma olmakta ve dopamin seviyelerinde oluşan bu değişiklik önce yoksunluğa, ardından devam eden şeker alımına yol açabilmektedir. Kanda yüksek şeker seviyeleri periferik olarak salınan iştah hormonlarının düzenlenmesinin yanı sıra, hipotalamik iştah peptitlerini de etkilemektedir. Beyin nörokimyasında şeker alımıyla oluşan bu değişiklikler büyüklük bakımından daha küçük olmasına rağmen madde kullanımı ile meydana gelen değişikliklere benzerdir. Şekerin insan sağlı̆̆ üzerinde yarattığı olumsuz sonuçlar göz önünde bulundurulduğunda oluşturabileceği bağımlılığın ciddi sonuçlar yaratacağı açıktır. Bu sebeplere dayanarak, șeker tüketiminin azaltılması adına, hem bireysel hem de toplum sağlığına yönelik, devletin ve endüstrinin birlikte hareket ettiği adımlar atılması önem taşımaktadır.

Anahtar kelimeler: Şeker, bağımlılık, dopamin, fruktoz, yeme bağımlılı̆̆

Yazının geliş tarihi: 11.02.2020

Yazının kabul tarihi:10.08.2020

Sorumlu yazar: Arş. Gör. Uzm. Sabriye Arslan, Gazi Üniversitesi, Sağlık Bilimleri Fakültesi, Beslenme ve Diyetetik Bölümü, 06560 Beşevler, Ankara. Tel: $03122162949 \quad$ Fax: 0312 2028226

E-posta: sabriyebolluk@ hotmail.com 


\title{
Sugar addiction: Real or imagened?
}

\begin{abstract}
Sugar is a delicious food that triggers the reward system in our brain because of its energy content and its taste. It is the main face of processed foods that cause food addiction. The general effects of sugar in the brain, in particular on reward pathways of the brain, have been an area of intense research and discussion. Sugar consumption activates the mesocorticolimbic system in a manner synonymous with substances of abuse. Increased dopamine D1 receptor binding and decreased D2 receptor binding in the brain due to sugar uptake, and this change in dopamine levels can lead to withdrawal, followed by continued sugar uptake. High levels of sugar in the blood affect the regulation of peripheral secreted appetite hormones, as well as hypothalamic appetite peptides. Although these changes in brain neurochemistry caused by sugar intake are smaller in size, they are similar to those caused by substance use. When the negative effects of sugar on human health are taken into consideration, it is clear that sugar addiction can create serious consequences. Based on these reasons, it is important to take steps in order to reduce sugar consumption, in which both the state and industry act together for both individual and public health.
\end{abstract}

Keywords: Sugar, addiction, dopamine, fructose, eating addiction

\section{Giriş}

Dünya Sağlık Örgütü (DSÖ) verilerine göre dünya çapında obezite sıklığı 1975’ten bu yana neredeyse üç katına ulaşmış olup ${ }^{1}$ öngörüler 2030 yılında dünya geneli yetişkin popülasyonunun \%57.8'inin obez veya fazla kilolu olacağı yönündedir. ${ }^{2}$ Türkiye'de ise yapılan Türkiye Beslenme ve Sağlık Araştırması-2010 sonuçlarına göre obezite oranı erkeklerde \%20.5, kadınlarda \%41.0 olmak üzere tüm yetişkin bireylerde $\% 30.3$ olarak belirlenmiștir. ${ }^{3}$ Dünya Sağlık Örgütü, sağlıksız ağırlık artışı ve obezite riskini azaltmak için 2015'ten itibaren besinlere eklenen şekerin günlük enerji alımının \%5'in altına düşürülmesini önermektedir.4 Eklenmiş şeker, Gıda ve Tarım Örgütü tarafından besinlere işleme ya da hazırlama sırasında eklenen șekerler ve șuruplar olarak tanımlanırken, Dünya Sağlık Örgütü bu tanıma meyve suları ve meyve konsantrelerinde doğal olarak bulunan şekerleri de dâhil ederek serbest şeker tanımını kullanmaktadır. ${ }^{5}$ Obezite ve metabolik sendromun nedenlerinden biri olarak eklenmiş şekerlere dair artan araştırmaların yanı sıra şeker potansiyel olarak bağımlılık yapan bir madde olarak da incelenmiştir. ${ }^{6}$

Bağımlılık, olumsuz sonuçlarla karşı karşıya kalınsa bile alışkanlık davranışını kontrol etmenin zorluğuyla karakterizedir. ${ }^{7}$ Bağımlılık üzerine ilk araștırmalar alkol, morfin ve nikotin gibi maddelerin bağımlılığı üzerine odaklanmıştır. Bağımlılık kavramının kapsamı o zamandan beri yeme, kumar, internet vb. içerecek şekilde genişlemiştir. Daha yakın dönemde ise şeker tüketiminin bağımlılık yapıcı etkilerine dair çalışmalar gündeme gelmiştir.8,9 Obezite prevelansında gün geçtikte görülen artışla beraber obez bireylerde gözlenen aşırı yeme ve tıkınırcasına yeme davranışları obezite sorununu yeme bağımlılığı olarak da gündeme getirmiş, hatta bazı araştırmacılar tarafından obezitenin ruhsal bir hastalık olarak Amerikan Psikiyatri Birliği Ruhsal Bozuklukların Tanısal ve İstatistiksel El Kitabı kriterlerine eklenmesi önerilmiştir.10,11 Bazı bilim adamları obez beynin besine, özellikle de eklenmiş şeker veya yağ içeren yüksek derecede işlenmiş besine, bağımlı olduğunu iddia etmektedir. ${ }^{12,13}$ Bağımlılık teriminin ortaya çıkışından önce, ilk olarak, çikolata, şeker ve karbonhidratlarca zengin yiyeceklere karşı aşırı istek duyma ile ilgili araştırmalar başlamıştır. ${ }^{10} \mathrm{Bu}$ araştırmalar psikolojik faktörlerin ağırlı kazanımını etkileyebileceğinin anlaşılmasına yardımcı olarak tekrar konuyu popüler hale getirmiştir. Theron Randolph ilk olarak 1956 yılında misır, süt, yumurta ve patates gibi 
çeşitli besinlerin bağımlılık benzeri tüketimini tanımlamak için "besin bağımlılığı" terimini kullanmıștır. ${ }^{14}$

Besin bağımlılığı modeli, bazı besinlerin aşırı tüketiminin madde bağımlılığı ile aynı nörobiyolojik çerçeve içinde anlaşılabileceğini ileri sürmektedir. Besin bağımlılığı geliştiren bireylerin, kontrol problemi, yoksunluk yaşamaları ve problemli besinler için aşırı istek duymaları, uyuşturucu madde kullanımıyla oluşan semptomlara benzer davranışlar gösterdiklerini düşündürmektedir. ${ }^{15}$ Laboratuar hayvanlarında yapılan çalışmalar, enerji alımını ve enerji talebini kontrol eden ve uzun süre vücut ağırlığını modüle eden homeostatik faktörlerin varlığını ortaya koymuştur. ${ }^{15,16}$ Homeostatik faktörlerin dişında besinlerin hedonik özelliklerinin günlük enerji gereksinimlerinin ötesinde beslenme davranışını etkileyebileceği ve obeziteye katkıda bulunabileceği bildirilmiştir. ${ }^{17}$

Şeker alımı ve obezite konusunda önemli tartışmalar mevcuttur.18 Şekerin (sükroz, fruktoz) doğrudan bir obezite nedeni olmadığına dair görüşler mevcut olsa da ${ }^{19}$ bazı çalışmalarda çocuklarda ve yetişkinlerde vücut ağırlı̆ı̆ındaki artış şekerle tatlandırılmış içeceklere (SSB) bağlanmaktadır. ${ }^{20}$ Ancak bu çalışmaların hiçbiri SSB'yi şeker bağımlılı̆̆ına bağlamadığı için kompulsif SSB tüketiminin vücut ağırlı̆̆ üzerindeki doğrudan etkisini yeterince değerlendirememektedir.

$\mathrm{Bu}$ derlemede, sağlık üzerindeki olumsuz etkileri dolayısıyla, öncelikli olarak eklenmiş şeker ve eklenmiş şekerin bağımlılık yapıcı etkilerine odaklanılmıştır.

\section{Yeme Bă̆ımlılı̆̆ı}

Yeme davranışı homeostatik ve hedonik olmak üzere iki farklı sistem tarafından düzenlenmektedir. Besin alımının düzenlenmesinde ve vücut ağırlığının korunmasında homeostatik faktörler ve homeostatik olmayan faktörler arasında nöral devrelerin olduğu gösterilmiştir. ${ }^{17,21}$ Bir bireyin tükettiği besin miktarını kontrol eden homeostatik faktörler (enerji depoları ve enerji talepleri tarafından düzenlenen) genellikle homeostatik olmayan (hedonik, yani beynin ödül sistemi, lezzet ve haz alma) sistemin etkilerine maruz kalmaktadır. ${ }^{22}$ Homeostatik enerji dengesini düzenlemek için besin tüketimi gereklidir. Bununla birlikte, insanlar besinleri haz alma veya rahatlık için de tüketirler. Lezzetli yiyecekler için hedonistik arzu, ödül ile ilgili olarak kabul edilir ve homeostatik düzenlemeyi geçersiz kılabilecek ve aşırı yeme davranışları ile sonuçlanabilecek uyumsuz veya negatif nöroplastisite ile görülebilir. ${ }^{23}$ Ödülle ilişkili sinyallerin homeostatik sinyalleri geçersiz kılabileceği, temel olarak, vücudun acil enerji gereksiniminden daha fazla besin tüketimine katkıda bulunabileceği gözlenmiştir.22,24 Son birkaç on yılda, tüketicilerin yüksek enerjili ve/veya fazla lezzetli yiyeceklere verdiği cevaplar ödülle ilgili sinyallerin etkilerinin bir yansıması olabilmektedir. ${ }^{13,24}$

\section{Şeker Bağımlılı̆̆ı}

Şekerin beyindeki, genel etkileri ve özellikle ödül yollarında beyindeki etkileri yoğun bir araştırma ve tartışma alanı olmuştur. Hayvan modellerinde yüksek yağll-yüksek şekerli diyet modeli, yiyecek bağımlılığının kuvvetli bir adayı olarak görünmektedir. ${ }^{25}$ Bazı araştırmacılar eklenmiş şekerlerden gelen tatlılığın bir şeker "bağımlılığı"na yol açabileceğini öne sürmüşlerdir. ${ }^{19,25} \quad$ Şeker, yiyecek bağımlılığına neden olan işlenmiş besinlerin temel özelliğini olușturmaktadır. ${ }^{19}$ Rafine edilmiş şekerlerin kokain, nikotin, alkol, tütün ve kafein gibi alıșkanlık oluşturduğu ileri sürülmektedir. ${ }^{26}$ Hem şeker hem de yapay tatlandırıcılarla tatlandırılmış içecekler rat modellerinde nükleus accumbenste (NAc) insanlarda zevk deneyimlerinin temeli olan dopamin salınımına yol açmakta ve zaman zaman dürtüsel aşırı yeme davranışı ile sonuçlanmaktadır. ${ }^{27}$ Burger tarafından yapılan bir çalışmada, genç erişkinlerin yüksek şekerli bir içeceğin tüketimi sırasında 21 güne kadar azalmış dorsal striatal tepki gösterdiği saptanmıştır. ${ }^{28}$ Shearrer ve arkadaşlarının $^{29}$ adölesanlarla yaptıkları çalışmada milkshakelerin daha yüksek şeker içeriğinin, tat alma ve hedonik bölgelerde 
daha yüksek tepki ürettiği belirlenmiștir. Şekerle tatlandırılmış içeceklerin potansiyel olarak bağımlılık yapıcı özelliklerinin araştırıldığı başka bir çalışmada ise üç günlük SSB bırakma döneminde, hafif şişman ve obez gençler arasında SSB'ler için aşırı istek ve yoksunluk belirtilerinde artış olduğu belirlenmiştir. ${ }^{30}$

Hipotalamus, besin alımını enerji gereksinimleri açısından düzenlerken, beynin striatal, limbik ve kortikal bölgeleri ve ödül yolu da dopamin aracılığıyla yeme davranışını tetiklemektedir. ${ }^{12}$ Ödül yolağı prefrontal korteks (PFC), amigdala (AMG), ventral-tegmental alan (VTA) ve nükleus accumbensten (NAc) oluşur ve madde kullanımıyla benzerdir. ${ }^{31}$ Nöroanatomik düzeyde, enerji homeostazının düzenlenmesi hipotalamusa bağlıdır, ancak ödül yolunun bir parçası olan NAc, şeker tüketiminin patofizyolojisinde çok önemlidir. ${ }^{32}$ Aynı zamanda ödül yolağının șekerin așırı tüketimi ile uyarıldığ ve böylece obezitenin gelișimine katkıda bulunduğu düşünülmektedir. ${ }^{32}$ Ödül yolu maddeyi veya davranışı istemek veya craving (aşerme/arzu) için motivasyon durumunu düzenleyen dopamin akışıyla oldukça ilişkilidir. ${ }^{33}$

Yiyeceklerin hedonik değeri, tüketimi ile ilgili ödül ve yeme arzusunu tetikleyen öğrenilmiş dış ipuçları, lateral hipotalamusta hipokampus ve oreksijenik hücreler ödül yolu arasındaki çift yönlü devre ile modüle edilmektedir. ${ }^{34}$ Lateral hipotalamusu aktive eden çalışmalar, beslenmenin glutamaterjik inhibisyonunu ve GABAerjik stimülasyonun inhibe edildiğini göstermektedir.35,36 Ayrıca bu GABAerjik nöronların bir alt grubu, VTA'dan hipotalamusa doğru uzanır ve şeker tüketimi için motivasyonu arttıran galanini eksprese etmektedir. ${ }^{37}$ Lateral hipotalamik oreksin nöronları, endojen melanokortin reseptör antagonistleri (nöropeptid Y (NPY) ve aguti ile ilișkili peptid ifade eden nöronlar (AgRP)) yoluyla hipotalamusun arcuat nukleusundan besin alımı ile ilgili girdi almaktadır. Ayrıca, metabolik homeostaz lateral hipotalamus tarafından glukoz, ghrelin ve leptin seviyeleri aracılığıyla algılanır ve yiyecek arama davranışlarını arttırır. ${ }^{38}$ Hipotalamik oreksinerjik ve anoreksinerjik yollar
NPY/AgRP ve POMC/CART peptidleri tarafından düzenlenir ve şeker tüketimi ile farklı şekillerde etkilenir. Oreksijenik yol NPY ve AgRP'yi içerir ve besin alımını uyarırken; anoreksijenik yol proopiomelanocortin (POMC), melanokortin reseptör agonisti $\alpha$-MS'nin bir öncüsü ve kokain ve amfetaminle düzenlenen transkripti (CART) içerir ve bu yol besin tüketimini engellemek için kullanılır.28 Yüksek yağlı bir diyetle beslenen ve daha sonra sükrozla tatlandırılmış su verilen farelerde, hipotalamusta POMC mRNA ekspresyonunun downregülasyonunu gösterilmiștir. ${ }^{39} \mathrm{Bu}$ bulgular șekerin bu yolun aktivasyonunu sınırlamada rol oynadığı ve böylece beslenme arzusunu artırdığını göstermektedir.

Serotonin, endojenopioidler ve endokannabinoidleri içeren bazı nörotransmitterler ise besinlerin kismen hedonik özelliklerini düzenleyerek ödüllendirici etkilerini olușturmaktadır.3,12 Yenen lezzetli bir besin ventral ve dorsals triatumda dopamin (DA) algılatmaktadır ve dorsal striatal DA salınımı besini yiyerek kazanılan memnuniyet seviyesi ile orantılıdır. ${ }^{33}$ Şeker veya yağ açısından zengin olan fazla lezzetli yiyecekler, bu ödül ve hedonik sistemleri güçlü bir şekilde tetikleyebilmekte ve gerekli enerji gereksinimlerinin üzerinde besin alımını teşvik edebilmektedir. ${ }^{31}$

Besin seçiminde yer alan nöral ağların lezzet veya beslenmeye (enerji içermesine) göre ayrılıp ayrılmadığını belirlemek için șeker tüketen farelerde striatal dopamin seviyeleri ölçüldüğü bir çalışma yapılmıştır.40 Kemirgenlere oral yoldan sükroz ve sükraloz yanı sıra tat unsurunu değerlendirebilmek için acılaștırılmış şeker solüsyonları hazırlamışlardır.40 Çalışmanın bir aşamasında yine tat unsurunu ekarte edebilmek için kemirgenlere intragastrikglukoz solüsyonu verilmiștir. Tellez ve ark. ${ }^{40}$ dopaminin salınımında ventral ve dorsal striatumda değişiklik olduğunu bildirmişlerdir. Çalışmanın sonucunda; 1. Oral yoldan tatlı sükraloz solüsyonu verildiğinde ventral striatum dopamin (VsDA) salımında artış olmuştur. Kemirgenlere yalnızca intra-gastrikglukoz 
solüsyonu verildiğinde her koşulda sadece VsDA artışı olmuştur. 2. Oral yoldan sükraloz solüsyonu ile intragastrik yoldan glukoz eşzamanlı verildiğinde dorsal striatum dopamin (DsDA) salınımında artış olmuştur. 3. Diğer bir aşamada intra-gastrik glukoz solüsyonu ile beraber acı tatta tatlı solüsyonu verildiğinde ise VsDA baskılanırken DsDA salınımı artmıştır. Ventraldeki dopamin artışını enerji tek başına arttırmayı sağlayabiliyorken, acı tat solüsyonu şekerle uyarılan VsDA salınımını baskılamıștır. ${ }^{40}$

\section{Dopamin}

Dopamin birçok reseptörü olan ve reseptörlerin konumuna göre farklı işlevleri yerine getiren bir nörotransmitterdir. D1'den D5'e kadar, beş farklı reseptör tanımlanmıştır. D1 ve D5 reseptörleri nöronların uyarılmasını sağlarken, D2, D3 ve D4 reseptörleri ise hedef nöronun inhibisyonuna neden olmaktadır. ${ }^{41}$ Lezzetli yiyeceklerin beynin ödüllendirme-öğrenme bölgelerinin dopamin sinyalizasyonu gibi aktive ettiği gözlenmiştir. ${ }^{33}$ Fazla şeker içeren besinlerin tekrarlanan alımı, artan dopamin reseptör D1 reseptör bağlanması ve singulat korteks, hipokampus, nükleusaccumbens ve locusceruleusta artan $\mu$-opioid reseptör bağlanması ile ilişkili olup bu değişiklikler madde bağımlılığı ile ilişkili değişikliklere benzerdir. ${ }^{42}$ Madde bağımlılarında görüldüğü gibi nükleus accumenbens ve dorsal striatumdaki postsinaptik dopamin reseptör D2 reseptörlerinin downregülasyonu yüksek yağlı/şekerli besinlerle beslenen hayvanlarda da bildirilmiştir.43,44

Yapılan bir çalışmada obez katılımcların lezzetli yiyeceklere maruz kalması, ödülle ilişkili beyin bölgelerinin hiper tepkiselliği ile de ilişkili bulunmuştur. ${ }^{45}$ Dopamin, besinlerin güçlendirici etkileriyle bağlantılıdır ve yapılan bir çalışmaya göre salınan dopamin miktarı ile yemekten alınan zevk pozitif korelasyon gösterirken, besin tüketiminin dorsal striatal dopamin salınımı ile sonuçlanmaktadır. ${ }^{33}$ Dopamin antagonistlerinin uygulanması ayrıca besin alımı ve vücut ağırlığında artışa neden olurken, dopamin agonistleri besin alımında ve buna bağlı vücut ağırlığında azalmaya neden olmaktadır.46

\section{Asetilkolin}

Nöralnikotinikasetilkolin reseptörleri (nAChRs) etanol, nikotin ve sükroz için biyolojik hedef olarak rol oynar ve GABA, glutamat, dopamin, serotonin, asetilkolib-n ve noradrenalinin nörotransmisyonunu düzenler. ${ }^{47}$ Limbik sistemde asetilkolinin homeostatik disregülasyonu bağımlılık davranışlarından olan motivasyon ve ödül arama davranışları ve relapsı düzenlediği gösterilmiştir. ${ }^{48}$ Dopamin artışı, doygunluğu erteleyen ve aşırı tüketimin yolunu açan beslenme sırasında asetilkolin salınımını geciktirir. ${ }^{39}$

\section{Melanin Konsantre Edici Hormon (MCH)}

Şekerin besleyici ödül olma özelliği üzerinde lateral hipotalamusta melanin konsantre edici hormon ( $\mathrm{MCH}$ ) nöronları da rol oynamaktadır. ${ }^{49}$ Melanin konsantre edici hormon tat duyusundan bağımsız olarak striataldopamin salınımını uyararak besinin ödül olma özelliğini kodlamaktadır.25,49 Kemirgenlerde, bu nöronlar, bağırsak girișinden bağımsız olarak hücre dışı glukoz seviyelerine cevaben ateşlenmekte; sırasıyla ventral ve dorsal striatuma iletilecek olan orta beyindeki dopamin nöronlarına yansımaktadırlar. Hayvanlar tipik olarak sükraloz yerine sükrozu tercih etseler de, $\mathrm{MCH}$ nöronlarından yoksun olan transgenik farelerde böyle bir tercih görülmemektedir Bu durum ise ödül olarak kodlanması için bu yolun elzem olduğunu göstermektedir.6,49 Şekerin tatlı tadının da ödüllendirici nitelikte oluşu enerji içermemesine rağmen sukraloz gibi tatlandırıcıların neden tüketildiği konusunda bir açıklama sunmaktadır. Bununla birlikte, tatlı tadın ödül özelliği enerji içeriğinden farklı bir nöral yolu aktive etmektedir. Farelerde şekerin enerji içeriği/besleyici ödülü, DA'nın esas olarak dorsalstriatumda salınmasına neden olurken, tatlılığının ödülü ventral striatumda yoğunlaşmaktadır. ${ }^{25}$ Farelerde sükralozun tüketilmesi, acı tat veren bir katkı eklenmesi dışında ventral striatumda artmış DA ile 
ilişkili oluşu ödülün, sükralozun başka bir özelliğinden ziyade lezzetli tada sahip oluşundan kaynaklandığını düşündürmektedir. ${ }^{40}$ Her ne kadar şekerin hem besleyici hem de tat ödülleri, bir dereceye kadar, nörolojik olarak farklı olsalar da, birbiri ardına meydana gelirler ve birbirleriyle ilişkilidirler. Son zamanlarda yapılan bir çalışmada, farelerin ventral striatumun nükleus accumbens (NAc) kabuğunda DA D2 reseptörü (DRD2) sinyali bozulan farelerde daha fazla dürtüsel sükroz alma, glukozla eşleștirilmiş tatların takviye/ödül kazanımının artması ve kötüleșen öğrenme esnekliği gözlenmiştir. ${ }^{50}$ Ayrica bu fareler glukozun metabolize edilmesinde daha az etkili bulunmuştur. $\mathrm{Bu}$ durum NAc'deki DRD2'nin hem çevresel glukoz seviyelerini hem de glikoz tüketiminin takviye/ödül öğrenimini düzenlemek için gerekli olduğunu göstermektedir. ${ }^{50} \mathrm{Bu}$ durum bu sistemdeki düzensizliğin neden aşırı yemeye neden olabileceğini açıklamaktadır.

\section{Serotonin}

Serotonerjik sistem de beslemenin hedonik olarak düzenlenmesinde yer almaktadır. Serotonin de dopamin gibi bağımlılık konusunda önemli bir role sahiptir. Serotonin düzeyindeki artış besin alımının azalmasına neden olurken azalmış serotonin düzeyi ise besin alımı için motivasyonun artmasına neden olur. ${ }^{51}$ Şeker ve kan şekerini hızlı yükselten yüksek glisemik indeksli karbonhidratlar beynin serotonin düzeyini etkilemektedir. ${ }^{52}$ Şeker ya da karbonhidratı yüksek bir yemek tüketimi sonrası beyin serotonininde dalgalanmalar meydana gelmektedir. Zamanla bu durum beyinde șeker bağımlılığını devam ettiren serotoninin tükenmesine yol açabilmektedir. $\mathrm{Bu}$ kişilerde aynı zamanda dopamin reseptörlerinin downregülasyonu ile dopamin eksikliği oluşma eğilimi de mevcuttur. ${ }^{52}$ Beslenme davranışında serotonin için önerilen etki mekanizması arkuat nükleusta AgRP ve POMC nöronları aracılığıla meydana gelmektedir. ${ }^{53}$ Serotonin taşıyıcıya bağlı polimorfik bölge patolojik korku durumlarında artan strese karşı hassasiyeti düzenler, strese bağlı fazla yemede rol alarak enerji alımını etkiler. ${ }^{54}$

\section{Hormonal Mekanizmalar: Leptin, ghrelin}

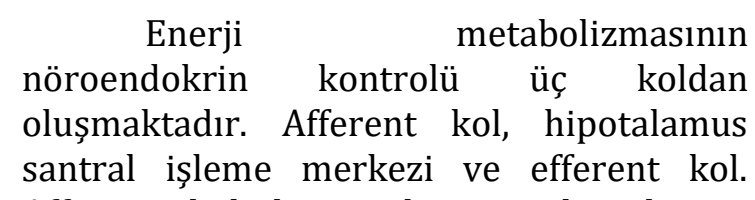
Afferent kol hormonları insülin, leptin, ghrelin, peptit YY periferdeki bilgiyi afferentvagus, glukagon benzeri peptit-1 (GLP-1) ve kolesistokinin aracilığ ile hormonal ve nöronal girdiler şeklinde hipotalamusun ventromedial kısmina iletmektedir.55 Ghrelin, leptin ve insülin hormonları, besin alımının homeostatik düzenleyicileridir ve dopaminerjik sistemlere olan etkilerinden dolayı, besin alımının homeostatik ve hedonik mekanizmalarına aracilık etmektedirler. ${ }^{56}$ Orta beyin dopamin nöronlarında leptin reseptör ekspresyonunun keşfi ile mezolimbik dopamin yollarının da leptinin besin alımı üzerindeki etkisine aracı olabileceği yönünde öneriler vardır. ${ }^{57}$ Ventral tegmental alandan NAc'ye projekt eden dopaminerjik nöronlar leptin ve insülin tarafından inhibe edilir ve ghrelin tarafından uyarılır. 58

\section{Fruktozun etkisi farklı mıdır?}

Fruktoz meyve ve balda doğal olarak bulunan bir monosakkarittir. En önemli kaynakları besinlere eklenen sükroz ve yüksek fruktozlu mısır şurubudur (HFCS). Yüksek fruktozlu misır şurubu misırdan birtakım üretim süreçleriyle elde edilen ve sükroza alternatif olarak kullanılan bir tatlandırıcıdır. ${ }^{9}$ Eklenmiş şeker içerisinde yer alan HFCS'nin önemli bir bileşeni olan fruktozun glikozdan farklı bir metabolik yolunun olması, beyin ve davranış üzerinde de farklı etkilere sahip olmasına neden olmaktadır. ${ }^{59}$

Glikoz, fruktozun bağırsaktan emilimini arttırırken, fruktoz, glikozun karaciğer tarafından alınması ve depolanması için bir katalizör görevi görür. ${ }^{60}$ Fruktoz, kan dolaşımına daha yavaş hızda emilir. ${ }^{61}$ Glikozun aksine fruktoz pankreatik beta hücreleri tarafından iyi emilmez ve bu 
nedenle insülin sekresyonunu çok az uyarır. ${ }^{62}$ İnsülin tokluğu arttırır ve besinden elde edilen ödül değerini azaltır bu nedenle fruktozun obezite gelişiminde glikoz tüketiminden daha karmaşık bir rol oynayabileceği düşünülmektedir. Gözlenen bu özelliklere ek olarak fruktoz bir öğünden sonra karbonhidrat oksidasyon oranını artırabilir, aynı zamanda tokluk seviyelerini de azaltabilir. ${ }^{60}$ Glikoz ve fruktoz, kan-beyin bariyerini geçme yeteneğine sahiptir. Bununla birlikte, bağırsak ve karaciğer fruktozu hızla parçaladığında, kan konsantrasyon seviyeleri genellikle düşüktür, bu da bariyeri geçmek için sadece küçük miktarlarla sonuçlanır.63

Yapılan bir çalışmada bireylere saf fruktoz veya glukozdan oluşan bir içecek verildikten on beș dakika sonra fonksiyonel MRI taraması sirasinda glukoz verilen bireylerde hipotalamus, insula, anteriorsingulat korteks ve striatumda başlangıç seviyesine göre anlamlı derecede düşük miktarda serebral kan akımı gösterilmiştir.64 Ayrıca hipotalamus, talamus, caudate veutamen arasinda daha fazla fonksiyonel bağlantı gösterilmiştir. Glukozdan sonra hipotalamus ve dorsal striatum arasındaki artan bağlantı, besleyici ödül yolunun birleşimini yansitacak şekilde yorumlanmıştır. Hipotalamik aktivitede azalma ve ödül merkezleriyle artan bağlantıya algılanan dolgunluk ve toklukta artış eşlik etmiştir. Buna karşılık, fruktoz içeceği tüketen bireylerde hipotalamusta düşük serebral kan akışı ile ilişkili bulunmamıştır. Bunun yerine talamus, hipokampus, posterior singulat korteks, fusiformgirus ve görsel kortekste azalmış serebral kan akışı ile ilişkili bulunmuştur. Fruktoz grubundakilerin talamus ve hipotalamus arasında bağlanma artmıș olmasına rağmen, glukoz grubunda dorsal striatum ile herhangi bir artış gözlemlenmemiştir. Buna paralel olarak, fruktoz tüketimi açlığı önemli ölçüde azaltmamıştır. Fruktoz tüketimi de yüksek enerjili besinlere glukoz tüketimi ile karşılaştırıldığında görsel kortekste daha güçlü bir cevapla ilişkilendirilmiştir. ${ }^{65}$

Jastreboff ve ark.66 yaptıkları çalışmada zayıf ve obez adölesanlarda glukoz ve fruktoz solüsyonlarına beyin yanıtını araştırmışlardır. Glukoz solüsyonu tüketiminde obez adölesanlarda yürütücü bölgeler olan prefrontal kortekste perfüzyon azalırken, hipotalamusun iştah ile ilgili bölgelerinde kan akımı artmıştır. Tam tersi zayıf adölesanlarda glukoz solüsyonu tüketiminde prefrontal kortekste perfüzyon artarken hipotalamusta değişim olmamıştır. Ayrıca glukoz solüsyonu tüketimi ardından obez adölesanlarda serum acil-ghrelin zayıflamış supresyon olurken dolaşımda artmış insülin seviyeleri gözlenmiștir. Hem glukoz hem de fruktoz solüsyonu alımının ardından acil-ghrelin ve insülin hormonlarındaki değişimlere hipotalamik, talamik ve hipokampal kan akışında artış eşlik etmiştir. Besin alımının homeostatik düzenlenmesinde anahtar rol oynayan hipotalamus obez adölesanlarda glukoz/fruktoz alımı ile uyarılırken zayıflarda uyarılmamıştır. Limbik sistem ve stiatumdaki ödül ve haz merkezleri de obez adölesanlarda fruktoz/glukoz alımı ile uyarılmıştır. Çalışmada santral sinir sisteminin glukoz ve früktoz solüsyonlarına farklı yanıt verdiği vurgulanmaktadır. ${ }^{66}$

Lindqvist, Baelemans ve ErlansonAlbertsson yaptıkları çalışmada ${ }^{67} \quad \% 23$ fruktoz içeren çözeltinin sıçanların serum insülin düzeylerinin iki haftadan sonra anlamlı olarak arttığını göstermiştir.67 İki haftalık yüksek fruktoz tüketimi periyodunun insülin dışında ghrelin ve leptin gibi diğer iștah düzenleyici peptitleri de modüle etmiştir. Her ne kadar leptin düzeyindeki artış \%23'lük glukoz çözeltisi ile taklit edilebilse de ghrelin düzeyindeki artışlar fruktoz alımına özel olmuştur. Her iki şekerin \%23'lük çözeltisi iki hafta sonra enerji alımı ve vücut ağırlığında anlamlı bir artışa neden olmuştur, ancak altı hafta boyunca, \%15'lik bir fruktoz çözeltisinin tüketimi sıçanlarda, vücut ağırlığını etkilememiştir. Periferik olarak salınan iştah hormonlarının modüle edilmesinin yanı sıra, yüksek kan şekeri seviyeleri hipotalamik iştah peptitlerini de etkilemektedir. Fruktoz veya glukoz solüsyonunun iki hafta tüketilmesinden sonra peptit YY (PYY), nöropeptid Y (NPY) ve propiomelanocortin (POMC) mRNA ekspresyonunun önemli ölçüde azaldığı gösterilmiştir. Kannabinoid1 (CB1) reseptörü mRNA ekspresyonu, sadece 
fruktoza yanıt olarak önemli ölçüde upregüle edilmiştir. Ayrıca endokannabinoid sinyal yolunun diğer bileşenleri şeker alımından etkilenir. Yüzde yirmi üç şeker çözeltilerinin (sükroz, glukoz ve fruktoz) tüketilmesinin, sentezleyici ve yıkıcl enzimlerin expresyonunu değiştirerek hipotalamikendokannabinoid düzeylerini etkilemiştir. Daha spesifik olarak, bir hafta sonra fosfolipaz C (PLC) 'de bir azalma gözlemlenmiștir; ancak sadece fruktoz yağ asidi amidhidrolaz (FAAH) ve diasilgliserollipaz (DAG) 1b'de artışa ve DAG1a mRNA'sında bir düşüşe neden olmaktadır. $\mathrm{Bu}$ durum bu etkilerin konsantrasyon ve/veya süreye bağlı bir mekanizma olduğunu düşündürmektedir. ${ }^{6}$

İştah sinyali peptidlerinin fruktozla indüklenmesi sadece kemirgen modellerinde değil, aynı zamanda insanlarda da gözlenmiştir. Page ve ark ${ }^{64}$, tek bir fruktoz içeceğinin (\%25), glukozda olduğu gibi (\%25) insülin değişikliği olmaksızın PYY düzeylerinde bir artışa neden olduğunu bulmuşlardır. Ne glukoz ne de fruktozun tek bir içeceği, plazma leptin ve ghrelin düzeylerinde saptanabilir farklılıklar yaratmamıştır. Fruktozun aksine, sadece glukozun, iştah düzenleyici beyin aktivitesini azaltarak tokluğa aracılık edebildiğini bulmuşlardır. İlginç bir şekilde, glukoz içeceği, hipotalamus ve striatum arasında fonksiyonel bağlantıda bir artışa yol açmış, bu da glukozun iştah kontrol merkezleri arasındaki iletişimi geliştirdiğini düşündürmektedir. Tersine fruktoz sadece hipotalamus ve talamus arasindaki bağlantıda bir artışa neden olmuştur ki bu durumun tokluğu indüklemek için yetersiz olduğunu düşündürmektedir. 64

\section{Bağımlılık Semptomları ve ilaç bağımlılığı ile karşılaştırılması}

\section{Şekerin bağımlılık potansiyeli} üzerine yapılan araştırmalar nispeten yeni, fakat gelişen bir alandır. Bu tür çalışmaların çoğunda eklenmiş şekerler ve madde kullanımının şiddetli istek, tolerans ve geri çekilme açısından paralelliklerini ortaya çıkaran hayvan modelleri kullanılmıştır.69 Hayvan modellerinde şekerlerin ve madde kullanımının semptomları arasında önemli bir örtüşme olduğu bildirilmektedir.70,71 Çeşitli çalışmalarda bahsedilen bu semptomlar arasında tıkınırcasına yeme (binge-eating), şiddetli istek, tolerans, yoksunluk (kullanımın kesilmesine bağlı olumsuz fizyolojik belirtiler), çapraz duyarlılaşma, çapraz tolerans, çapraz bağımlılık, ödül ve opioid etkinin yer aldığı belirtilmektedir.72-74 Aynı ödül ile ilişkili beyin yapıları (NAc kabuğu, caudat çekirdeği), hem şeker hem de madde kullanımına karşılık verdikleri için, fiziksel ve psikolojik tepkilerin yanı sıra bağımlılık yapan davranışlar üretme mekanizmalarıyla ilişkili görünmektedir.74

Sadece birkaç haftadan aylara kadar uzanan kronik şeker alımından sonra, şeker alımı periyotları aralarında, uyuşturucu madde kullanımındaki gibi; Dopamin D1 resöptör bağlanmasında artış ve D2 reseptör bağlantısında azalma olmaktadır. Dopaminin bu reseptörlere bağlanmasında bir azalmaya bağlı olarak beyinde dopamin eksikliği olabilmektedir. Kokain ve morfindeki gibi $\mu$ reseptör bağlantısında ise artış olmaktadır. ${ }^{43}$ Dopamin seviyesi beyinde düşük olduğunda, bu durum daha sonra yoksunluğa, dolayısıyla devam eden şeker alımına yol açabilmektedir. Dopaminin yüksek ve alçak seviyeleri şeker alımına bağımlılığı sürdürecek bir kısır döngüye yol açmaktadır.69,75

Az sayıda çalışma insanlarda şeker bağımlılığını spesifik olarak incelemiştir ve destekleyici kanıtların çoğu hayvan çalışmasından gelmektedir. Hayvan çalışmalarının insanlara uyarlanmasında, insanların nadiren şekeri izole olarak tüketmeleri nedeniyle metodolojik bir takım zorluklar ve saf şeker tüketimini inceleyen çalışmaların ekolojik geçerliliğinin de sınırlı olması nedeniyle bu alandaki insan çalışmaları daha sınırlıdır. ${ }^{25}$ Tatlı veya lezzetli besinlerin tüketiminin davranışsal ve nöral etkilerini kapsayan birtakım çalışma sonuçları mevcut olsa da bu sonuçlar şeker bağımlılığına dair daha dolaylı veriler sağlayabilmektedir. ${ }^{25}$ Ancak rat modellerinde şeker bağımlılığı kanıtlarının direkt olarak insanlara uygulanması da doğru olmayabilir. Yağ ratlarda şeker yoksunluğu semptomlarına karşı koruyucu olduğu için, insanlarda doğal olarak daha 
çeşitli olan diyetler nedeniyle, insanlarda saf şeker yoksunluğunu tanımlamakta rat modelleri başarısız olabilir. ${ }^{6}$ Bununla birlikte, risk faktörleri, nörobiyolojik değişiklikler için madde bağımlılığı ve aşırı şeker alımının davranışsal etkileri arasındaki örtüşmeler, eklenmiş şekerin bağımlılık yapan maddelerin yol açtığı davranışlara benzer davranışları tetikleyebilecek, sorunlu bir madde olduğunu düşündürmektedir. Fazla tüketilen eklenmiş şekerin, ve özellikle fruktozun sağlık üzerinde olumsuz etkileri olduğu açık olsa da, șekerin beyni nasıl etkilediği de dahil olmak üzere bu etkilerin mekanizmalarını incelemek için daha fazla araştırmaya ihtiyaç vardır.

\section{Sonuç}

Günümüzde şeker açısından zengin diyetlere erişim kolaylığı obeziteye katkıda bulunan çevresel faktörlerden biridir. Ancak şeker tüketimi öz kontrol mekanizmalarını geçersiz kılan ve obeziteye yol açan üstün bir nörolojik ödül sinyali üretme yeteneğine sahip olabilir. Fazla şeker içeren besinlerin tekrarlanan alımı, artan dopamin reseptör D1 reseptör bağlanması ve artan $\mu$-opioid reseptör bağlanması ile ilişkili olup, bu değişiklikler madde bağımlılığı ile ilişkili değişikliklere benzerdir. Ayrıca dopamin artışı, tokluk sinyali için gereken asetilkolin salınımını geciktirir. Bu nöroadaptasyonlar dolayısıyla sükroz tüketimi algılama biçimimizi, duygu işleme sürecimizi ve nihai davranışlarımızı değiştirme yeteneğine sahip olabilir. $\mathrm{Bu}$ konudaki hayvan çalışmaları sonuçları desteklese de insanlarla yapılan çalışmalardaki kanıtlar henüz yeterli değildir. Ancak bu konudaki nöral mekanizmalarının daha iyi anlaşılması obezite tedavilerinin geliștirilmesine yardımcı olabilir. Bununla birlikte şeker tüketimini azaltmak, sağlıklı beslenme davranışını teşvik etmek ve genel fiziksel ve davranışsal sağlığı sürdürmek için oldukça önemlidir. Şekerin insan sağlı̆̆ üzerinde yarattığı olumsuz sonuçlar göz önünde bulundurulduğunda şekerin oluşturabileceği bağımlılığın ne kadar ciddi sonuçlar yaratacağı açıktır. Ambalajlı hazır yiyecekler satın alınırken etiket üzerinde şeker içeriği ve türü okunmalı ve tercihi ona göre yapılmalıdır. Etikette yer alan kahverengi şeker, mısır kaynaklı tatlandırıcılar, mısır şurubu, meyve suyu konsantresi, yüksek fruktozlu mısır şurubu, bal, invert şeker, malt şekeri, melas (şeker tortusu), şurup, ham şeker, şeker, dekstroz, früktoz, glikoz, laktoz, maltoz, sukroz ilave şekeri göstermektedir. Etiketinde "ilave şeker içermez" ibaresi olan şeker ilave edilmemiş olanlar tercih edilmelidir. Şekerle tatlandırılmış içeceklerin tüketimi azaltılmalı, eklenmiş şeker içermeyen içeceklerin seçilmesi, konserve meyve, meyve sosu vb. ürünlerde eklenmiş şeker içermeyen ürünlerin seçilmesi, tatlı atıştırmalıklar tüketiliyorsa porsiyon boyutlarının sinırlandırılması günlük alınan şeker miktarını azaltmaya yardımcı olacaktır. Toplam günlük alınan şeker miktarı, günlük enerji gereksiniminin $\% 10$ ' unu geçmemelidir, hatta bu değer $\% 5$ 'in altına düşürülmelidir. Şeker tüketiminin azaltılması adına hem bireysel hem de toplum sağlığına yönelik devletin ve endüstrinin birlikte hareket ettiği adımlar atılması önem taşımaktadır.

Yazar katkısı: Tüm yazarlar makalenin planlanması, yazılması, revize edilmesi ve son halinin kabul edilmesinde katkıda bulunmuştur.

Çıkar çatışması: Yazarlar arasında herhangi bir çıkar çatışması bulunmamaktadır.

Mali destek: Bu çalışma sırasında kamu, ticari veya kar amacı gütmeyen sektörlerdeki fon ajanslarından herhangi bir destek alınmamıştır.

\section{Kaynaklar}

1. Dünya Sağlık Örgütü. Fact Sheet: Obesty and overweight. Erişim yeri: https://www.who.int/en/newsroom/fact-sheets/detail/obesity-andoverweight, Erişim tarihi: 07.07.2019

2. Dimitrijević I, Popović N, Sabljak V, Škodrić-Trifunović V, Dimitrijević N. Food addiction-diagnosis and treatment. Psychiatr Danub 2015;27(1),101-106. 
3. T.C. Sağlık Bakanlığı Yayın No: 931. Sağlık Araştırmaları Genel Müdürlügü Yayın No: SB-SAG-2014/02. Erişim yeri: https://hsgm.saglik.gov.tr/depo/birimle r/saglikli-beslenme-hareketli-hayat$\mathrm{db} /$ Yayinlar/kitaplar/digerkitaplar/TBSA-Beslenme-Yayini.pdf, Erișim tarihi: 06.02.2020.

4. Dünya Sağlık Örgütü (DSÖ). Guideline: sugars intake for adults and children: World Health Organization; 2015. Erişim yeri:

https://apps.who.int/iris/bitstream/han dle/10665/149782/9789241549028 en g.pdf;jsessionid=C3DA898D6AEF5BE9D1 FC52A3FD98ACFC?sequence $=1$, Erişim tarihi: 07.07.2019

5. Çiçek B. Eklenmiş şekerler ve sağlık. Turkiye Klinikleri J Nutr Diet-Special Topics 2016;2(1):31-34.

6. Freeman CR, Zehra A, Ramirez V, Wiers CE, Volkow ND, Wang GJ. Impact of sugar on the body, brain, and behavior. Front Biosci (Landmark Ed) 2018;23:2255-2566.

7. Lindgren E, Gray K, Miller G, Tyler R, Wiers CE, Volkow ND, Wang GJ. Food addiction: A common neurobiological mechanism with drug abuse. Front Biosci (Landmark Ed) 2018;23:811-836.

8. Klenowski PM, Shariff MR, Belmer A, Fogarty MJ, Mu EW, Bellingham MC, Bartlett SE. Prolonged consumption of sucrose in a binge-like manner, alters the morphology of medium spiny neurons in the nucleus accumbens shell. Front Behav Neurosci 2016;10:54.

9. Benton D. The plausibility of sugar addiction and its role in obesity and eating disorders. Clin Nutr 2010:29(3):288-303.

10. Öyekçin DG, Deveci A. Yeme Bağımlılığının etyolojisi. Psikiyatride Guncel Yaklasimlar 2012;4(2):138.

11. Moreno C, Tandon R. Should overeating and obesity be classified as an addictive disorder in DSM-5? Curr Pharm Des 2011;17(12):1128-31.

12. Volkow ND, Wise RA, Baler R. The dopamine motive system: Implications for drug and food addiction. Nat Rev Neurosci 2017;18(12):741.

13. Carlier N, Marshe VS, Cmorejova J, Davis C, Müller DJ. Genetic similarities between compulsive overeating and addiction phenotypes: A case for "food addiction"? Curr Psychiatry Rep 2015;17(12):96.

14. Meule A. Focus: Addiction: Back by popular demand: A narrative review on the history of food addiction research. Yale J Biol Med 2015;88(3):295.

15. Schulte EM, Avena NM, Gearhardt AN. Which foods may be addictive? The roles of processing, fat content, and glycemic load. PloS one 2015;10(2):e0117959.

16. Woods SC. The control of food intake: behavioral versus molecular perspectives. Cell Metab 2009;9(6):489498.

17. Hagan S, Niswender KD. Neuroendocrine regulation of food intake. Pediatr Blood Cancer 2012;58(1):149-153.

18. Khan TA, Sievenpiper JL. Controversies about sugars: Results from systematic reviews and meta-analyses on obesity, cardiometabolic disease and diabetes. Eur J Nutr 2016;55(2):25-43.

19. Rippe J, Angelopoulos T. Relationship between added sugars consumption and chronic disease risk factors: Current understanding. 2016:8(11):E697.

20. Te Morenga L, Mallard S, Mann J. Dietary sugars and body weight: Systematic review and meta-analyses of randomised controlled trials and cohort studies. BMJ 2013;346:e7492.

21. Saper CB, Chou TC, Elmquist JK. The need to feed: Homeostatic and hedonic control of eating. Neuron 2002;36(2):199-211.

22. Begg DP, Woods SC. The endocrinology of food intake. Nat Rev Endocrinol 2013;9(10):584.

23. Kenny PJ. Reward mechanisms in obesity: New insights and future directions. Neuron 2011;69(4):664-79.

24. Alonso-Alonso M, Woods SC, Pelchat M, Grigson PS, Stice E, Farooqi S, Khoo CS, 
Mattes RD, Beauchamp GK. Food reward system: current perspectives and future research needs. Nutr Rev 2015;73(5):296-307.

25. Westwater ML, Fletcher PC, Ziauddeen H. Sugar addiction: the state of the science. Eur J Nutr 2016;55(2):55-69.

26. Ahmed SH, Guillem K, Vandaele Y. Sugar addiction: Pushing the drug-sugar analogy to the limit. Curr Opin Clin Nutr Metab Care 2013;16(4):434-439.

27. de Silva PN. Are sweetened drinks a gateway to alcohol, opiate and stimulant addiction? Summary of evidence and therapeutic strategies. Med Hypotheses. 2020;135:109469.

28. Burger KS. Frontostriatal and behavioral adaptations to daily sugar-sweetened beverage intake: A randomized controlled trial. Am J Clin Nutr. 2017;105(3):555563.

29. Shearrer GE, Stice E, Burger KS. Adolescents at high risk of obesity show greater striatal response to increased sugar content in milkshakes. Am J Clin Nutr. 2018;107(6):859-866.

30. Falbe J, Thompson HR, Patel A, Madsen KA. Potentially addictive properties of sugar-sweetened beverages among adolescents. Appetite. 2019;133:130-137.

31. Sinha R. 2018. Role of addiction and stress neurobiology on food intake and obesity. Biol Psychol 2018;31:5-13.

32. Murray S, Tulloch A, Criscitelli K, Avena NM. Recent studies of the effects of sugars on brain systems involved in energy balance and reward: Relevance to low calorie sweeteners. Physiol Behav 2016;164, 504-508.

33. Small DM, Jones-Gotman M, Dagher A. Feeding-induced dopamine release in dorsal striatum correlates with meal pleasantness ratings in healthy human volunteers.

Neuroimage 2003;19(4):1709-1715.

34. Petrovich GD, Hobin MP, Reppucci CJ. Selective Fos induction in hypothalamic orexin/hypocretin, but not melaninconcentrating hormone neurons, by a learned food-cue that stimulates feeding in sated rats. Neuroscience 2012;224:7080.

35. Jennings JH, Rizzi G, Stamatakis AM, Ung RL, Stuber GD. The inhibitory circuit architecture of the lateral hypothalamus orchestrates feeding. Science 2013;341(6153):1517-1521.

36. Jennings $\mathrm{JH}$, Ung RL, Resendez SL, Stamatakis AM, Taylor JG, Huang J, at al. Visualizing hypothalamic network dynamics for appetitive and consummatory behaviors. Cell 2015;160(3):516-527.

37. Bocarsly ME. Pharmacological interventions for obesity: Current and future targets. Curr Addict Rep 2018;5(2):202-211.

38. A, Kunii K, Nambu T, Tsujino N, Sakai A, Matsuzaki I, Miwa Y, Goto K, Sakurai T. Orexin-induced food intake involves neuropeptide Y pathway. Brain Res 2000;859(2):404-409.

39. Soto M, Chaumontet C, Even PC, Nadkarni N, Piedcoq J, Darcel N, Tomé D, Fromentin G. Intermittent access to liquid sucrose differentially modulates energy intake and related central pathways in control or high-fat fed mice. Physiol Behav 2015;4453.

40.Tellez LA, Han W, Zhang X, Ferreira TL, Perez IO, Shammah-Lagnado SJ, van den Pol AN, de Araujo IE. Separate circuitries encode the hedonic and nutritional values of sugar. Nat Neurosci 2016;19(3):46570 .

41. Ayano G. Dopamine: receptors, functions, synthesis, pathways, locations and mental disorders: Review of literatures. J Ment Disord Treat 2016;2(120):2.

42. Colantuoni C, Schwenker J, McCarthy J, Rada P, Ladenheim B, Cadet JL, Schwartz GJ, Moran TH, Hoebel BG. Excessive sugar intake alters binding to dopamine and mu-opioid receptors in the brain. Neuroreport 2001;12(16):3549-3552.

43. Johnson PM, Kenny PJ. Dopamine D2 receptors in addiction-like reward dysfunction and compulsive eating in 
obese rats. Nat Neurosci 2010;13(5):63541.

44. Stice E, Yokum S, Blum K, Bohon C. Weight gain is associated with reduced striatal response to palatable food. $J$ Neurosci 2010;30(39):13105-13109.

45. Stice E, Yokum S, Bohon C, Marti N, Smolen, A. Reward circuitry responsivity to food predicts future increases in body mass: Moderating effects of DRD2 and DRD4. Neuroimage 2010;50(4):16181625.

46. Epstein LH, Leddy JJ, Temple JL, Faith MS. Food reinforcement and eating: A multilevel analysis. Psychol Bull 2007;133(5):884.

47. Shariff M, Quik M, Holgate J, Morgan M, Patkar OL, Tam V, Belmer A, Bartlett SE. Neuronal nicotinic acetylcholine receptor modulators reduce sugar intake. PloS One 2016;11(3):e0150270.

48. Rahman S, Engleman EA, Bell RL. Nicotinic receptor modulation to treat alcohol and drug dependence. Front Neurosci 2015;8:426.

49. Domingos AI, Sordillo A, Dietrich MO, Liu ZW, Tellez LA, Vaynshteyn J, Ferreira JG, Ekstrand MI, Horvath TL, de Araujo IE, Friedman JM. Hypothalamic melanin concentrating hormone neurons communicate the nutrient value of sugar. Elife 2013;2:e01462.

50. Michaelides M, Miller ML, DiNieri JA, Gomez JL, Schwartz E, Egervari G, Wang GJ, Mobbs CV, Volkow ND, Hurd Y. Dopamine D2 Receptor signaling in the nucleus accumbens comprises a metabolicc cognitive brain interface regulating metabolic components of glucose reinforcement. Neuropsychopharmacology 2017;42(12):2365.

51. Halford JC, Boyland EJ, Blundell JE, Kirkham TC, Harrold JA. Pharmacological management of appetite expression in obesity. Nat Rev Endocrinol 2010;6:255.

52. Wurtman RJ, Wurtman JJ. Brain serotonin, carbohydrate-craving, obesity and depression. Obes Res 1995;3(S4):477S-480S.
53. Sohn JW, Elmquist JK, Williams KW. Neuronal circuits that regulate feeding behavior and metabolism. Trends Neurosci 2013;36:504-512.

54. Capello, A.E., Markus, C.R., 2014. Differential influence of the 5-HTTLPR genotype, neuroticism and real-life acute stress exposure on appetite and energy intake. Appetite 2014;77:83-93.

55. Böber E. Obezite Fizyopatolojisi. Turkiye Klinikleri J Pediatr Sci 2015;11(3):1-6.

56. Hebebrand J, Albayrak Ö, Adan R, Antel J, Dieguez C, de Jong J, Leng G, Menzies J, Mercer JG, Murphy M, van der Plasse G, Dickson SL. "Eating addiction" rather than "food addiction" better captures addictive-like eating behavior. Neurosci Biobehav Rev 2014;47:295-306.

57. Lerma-Cabrera JM, Carvajal F, LopezLegarrea P. Food addiction as a new piece of the obesity framework. Nutr J 2015;15(1):5.

58. Palmiter RD. Is dopamine a physiologically relevant mediator of feeding behavior? Trends Neurosci 2007;30:375-381.

59. Arslan S, Şanlıer N. Fruktoz ve sağlık. Mersin Univ Saglık Bilim Derg 2016;9(3):150-158.

60. Laughlin MR. Normal roles for dietary fructose in carbohydrate metabolism. Nutrients 2014;6:3117-3129.

61. Teff KL, Elliott SS, Tschöp M, Kieffer TJ, Rader D, Heiman M, Townsend RR, Keim NL, D'Alessio D, Havel PJ. Dietary fructose reduces circulating insulin and leptin, attenuates postprandial suppression of ghrelin, and increases triglycerides in women. $J$ Clin Endocrinol Metab 2004;89:2963-2972.

62. Kyriazis GA, Soundarapandian MM, Tyrberg B. Sweet taste receptor signaling in beta cells mediates fructose-induced potentiation of glucose-stimulated insulin secretion. Proc Natl Acad Sci 2012;109:E524-E532.

63. Gonzalez JT, Betts JA. Dietary fructose metabolism by splanchnic organs: Size matters. Cell Metab 2018;27:483-485. 
64. Page KA, Chan O, Arora J, BelfortDeaguiar R, Dzuira J, Roehmholdt B, Cline GW, Naik S, Sinha R, Constable RT, Sherwin RS. Effects of fructose vs glucose on regional cerebral blood flow in brain regions involved with appetite and reward pathways. JAMA 2013;309(1):6370.

65. Luo S, Monterosso JR, Sarpelleh K, Page KA. Differential effects of fructose versus glucose on brain and appetitive responses to food cues and decisions for food rewards. Proc Natl Acad Sci U $S$ A. 2015;112(20), 6509-6514.

66. Jastreboff AM, Sinha R, Arora J, BelfortDeaguiar R, Dzuira J, Roehmholdt B, Cline GW, Naik S, Sinha R, Constable RT, Sherwin RS. Altered brain response to drinking glucose and fructose in obese adolescents. Diabetes 2016;65(7):19291939.

67. Lindqvist A, Baelemans A, ErlansonAlbertsson C. Effects of sucrose, glucose and fructose on peripheral and central appetite signals. Regul Pept 2008;150(13):26-32.

68. Erlanson-Albertsson C, Lindqvist A. Fructose affects enzymes involved in the synthesis and degradation of hypothalamic endocannabinoids. Regul Pept 2010;161(1-3):87-91.

69. DiNicolantonio JJ, O’Keefe JH, Wilson WL. Sugar addiction: Is it real? A narrative review. Br J Sports Med 2018;52(14):9103.

70. Volkow ND, Wise RA. How can drug addiction help us understand obesity? Nat Neurosci 2005;8(5):555.

71. Lenoir M, Serre F, Cantin L, Ahmed SH. Intense sweetness surpasses cocaine reward. PloS One 2007;2(8):e698.

72. Avena NM, Rada P, Hoebel BG. Evidence for sugar addiction: Behavioral and neurochemical effects of intermittent, excessive sugar intake. Neurosci Biobehav Rev 2008;32(1):20-39.

73. Bello NT, Guarda AS, Terrillion CE, Redgrave GW, Coughlin JW, Moran TH. Repeated binge access to a palatable food alters feeding behavior, hormone profile, and hindbrain c-Fos responses to a test meal in adult male rats. Am J Physiol Regul Integr Comp Physiol 2009;297(3):R622-31.

74. Smith JE, Co C, Coller MD, Hemby SE, Martin TJ. Self-administered heroin and cocaine combinations in the rat: Additive reinforcing effects-Supra-additive effects on nucleus accumbens extracellular dopamine. Neuropsychopharmacology 2006;31(1):139.

75. Volkow ND, Wang GJ, Baler RD. Reward, dopamine and the control of food intake: implications for obesity. Trends Cog Sci 2011;15(1):37-46. 